\title{
A Brief Reconnoitre about Effects of MMP9 on Aortic Dissection
}

\author{
MMP9 Geninin Aort Diseksiyonundaki Olası Etkilerinin Araştırılması
}

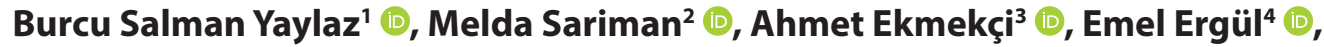 \\ Mahmut Uluganyan $^{5}$ (D), Fulya $\operatorname{Coşan}^{6}{ }^{\mathbb{D}}$, Özgün Melike Gedar Totuk ${ }^{\mathbb{1}}$, Neslihan Abaci ${ }^{1}$ (D)
}

\author{
'Department of Genetics, Aziz Sancar Institute of Experimental Medicine, Istanbul University, İstanbul, Turkey \\ ${ }^{2}$ Istinye University Molecular Cancer Research Center, İstanbul, Turkey \\ 3Department of Cardiology, Hospital of Medical Park, Istanbul, Turkey \\ ${ }^{4}$ Department of Medical Biology and Genetics, Faculty of Medicine, Kocaeli University, Kocaeli, Turkey \\ ${ }^{5}$ Department of Cardiology, Faculty of Medicine, Bezmialem University, İstanbul, Turkey \\ ${ }^{6}$ Department of Rheumatology, Faculty of Medicine, Bahçeşehir University, İstanbul, Turkey \\ 'Department of Ophthalmology, Faculty of Medicine, Bahçeşehir University, İstanbul, Turkey
}

ORCID ID: B.S.Y. 0000-0002-9144-3899; M.S. 0000-0003-0898-529X; A.E. 0000-0001-5424-149X; E.E. 0000-0003-0473-4020; M.U. 0000-0002-4578-4537; F.C. 0000-0002-5630-8640; Ö.M.G.T. 0000-0003-1863-6501; N.A. 0000-0002-9962-4010

Cite this article as: Salman Yaylaz B, Sariman M, Ekmekçi A, Ergul E, Uluganyan M, Coşan F, Gedar Totuk ÖM, Abacı N. A brief reconnoitre about effects of MMP9 on aortic dissection. Experimed 2021;11(1): 12-20.

\section{ABSTRACT}

Objective: Matrix metalloproteinases (MMPs) are the extracellular matrix regulators that frequently investigate cardiovascular diseases and cancer metastasis. Our study aimed to examine specific polymorphisms in the MMP9 gene in our patients with aortic dissection and compare the effect of MMP9 on aortic dissection with expression datasets.

Materials and Methods: Q279R and P574R polymorphisms were analyzed in 44 aortic dissection patients and 40 healthy donors via polymerase chain reaction-restriction fragment length polymorphism. (PCR-RFLP) methods. Q279R and P574R prevalence was statistically compared with the medical data of the patients. Additionally, we collected datasets of aortic dissection from NCBI GEO to reanalyze GEO2R and RStudio to see metalloproteinase activity on samples. Later, enrichment analysis was processed on widely used databases.

Results: Genotypic distribution of alleles was similar in the two study groups. In addition to this, female CG carriers had a higher risk of developing aortic dissection than those of males. As the results of the protein-protein interaction analysis of MMP9 and patients' clinical data, hypertension was found to be the significant outcome of P574R variation in the patients. In array analysis, MMP9 expression did not change critically, but TIMPs had been downregulated in many samples. Also, MMP9 targeted miRNA expression levels were detected as low in aortic tissue and blood.

Conclusion: Q279R and P574R are two polymorphisms that do not directly affect $M M P 9$ protein structure. Consequently, studied polymorphisms and performed meta-analysis show that MMP9 does not spark off the phenotype but sets the stage for aortic dissection development as seen in the statistical results. Furthermore, enrichment analysis on datasets shows $M M P 9$ was not a primary reason for vascular remodeling. Keywords: Aortic dissection, MMP9, Q279R, P574R, gene expression data

\section{öz}

Amaç: Kardiyovasküler hastalıklar ve kanser metastazında sıklıkla araştırılan matriks metalloproteinazlar (MMPs) ekstraselüler matriks düzenleyicileridir. Çalışmamız, aort diseksiyonu olan hastalarda MMP9 genindeki spesifik polimorfizmleri incelemeyi ve $M M P 9$ 'un aort diseksiyonu üzerindeki etkisini ekspresyon veri setleri ile karşılaşıımayı amaçlamaktadır.

Gereç ve Yöntem: Q279R ve P574R polimorfizmleri 44 aort diseksiyon tanısı almıs ve 40 sağlıkıı bireyde polimeraz zincir reaksiyonu - restriksiyon parça uzunluğu polimorfizmi (PCR-RFLP) yöntemiyle çalışıldı. Q279R ve P574R prevalansı istatistiksel olarak hastaların tıbbi verileriyle karşılaştıııldı. Buna ek olarak, NCBI GEO veri tabanından aort diseksiyon veri setleri toplandı ve MMP9 ifadesindeki farklılıkları görmek amacıyla bu veri setleri GEO2R ve RStudio ile yeniden analiz edildi. Elde edilen sonuçların informatik analizi için çevrimiçi veri tabanları kullanıldı.

Bulgular: CG alleli taşıyıcısı kadınların aort diseksiyonu geliştirme riski erkeklerden daha yüksek bulunmasına rağmen her iki çalışma grubunda da allellerin genotipik dağııımı benzer bulunmuştur. MMP9'un protein-protein etkileşim analizinin ve hastaların tıbbi verilerinin incelenmesinin sonucu olarak, P574R hipertansiyonu olan hastalarda önemli bir bulgu olarak değerlendirilmiştir. Array verisi analizinde ise MMP9 ifadesinde kritik bir değişim gözlemlenmemiş olup, birçok örnekte TIMP ifade seviyelerinde azalma tespit edilmiştir. Ayrıca MMP9'u hedefleyen miRNA ekspresyon seviyelerinin aort dokusu ve kanda düşük olduğu saptanmıştır.

Sonuç: Q279R ve P574R, MMP9 protein yapısını doğrudan etkilemeyen iki polimorfizmdir. İncelenen polimorfizmler ve gerçekleștirilen meta-analizler, MMP9'un fenotipi doğrudan etkilemediği, ancak istatistiksel sonuçlarda görüldüğü gibi aort diseksiyonu gelişimi için zemin hazırladığını göstermektedir.

Anahtar Kelimeler: Aort diseksiyon, MMP9, Q279R, P574R, gen ifade verisi 


\section{INTRODUCTION}

Aortic dissection is caused by the creation of a false lumen in the aorta. An intimomedial tear allows blood flow to enter the aortic wall by creating a false lumen or a secondary channel, called an aortic dissection, a catastrophic manifestation of the acute aortic syndrome. Aortic dissection has the highest mortality rate among cardiovascular diseases due to the rising of lethality rate at $1 \%$ per hour. Diagnosis of dissection is done by scanning the aorta and its branches with computed tomography (1-3). Predisposition to acute aortic dissection has been associated with atherosclerosis vasculitis, bicuspid aortic valves, male gender, long-term arterial hypertension, and collagen-based disorders such as Marfan's and Ehlers-Danlos syndromes (4-6).

Matrix metalloproteinases (MMPs) are extracellularly acting, zinc-dependent endopeptidases that break the peptide bonds of nonterminal amino acids. MMPs are involved in the developmental stages of the extracellular matrix and have been implicated in several collagen-based disorders $(7,8)$. MMPs bind to adhesion and extracellular matrix proteins and have been divided into types based on their substrates, including membrane, gelatinase, stromelysin, matrilysin, and collagenase $(9,10)$. Matrix metalloproteinase 9 (MMP9), also known as the 92 $\mathrm{kDa}$ type IV collagenase or gelatinase $\mathrm{B}$, is categorized in the gelatinase subgroup and has a significant role in extracellular matrix degradation $(7,8)$. MMP9 in humans contains an $\mathrm{NH}_{2}$-terminal prodomain, a $\mathrm{COOH}$-terminal hemopexin-like domain, a catalytic domain, and a linker domain. The MMP9 gene is positioned at the chromosome region 20q11.2-13.1.8 and has 13 exons and 12 introns. MMP9 is secreted from various types of cells, such as fibroblasts, macrophages, and neutrophils (8-11). MMP9 is positively regulated by transcription factors (such as NF-kappa $\beta$ and activator protein-1) and polyomavirus enhancer A-binding protein-3. Tissue inhibitors of metalloproteinases inhibit MMP9 by binding to the zymogen forms of the enzyme. Recent studies have revealed that MMP9 polymorphisms are associated with cardiovascular diseases, such as hypertension, myocardial infarction, and atherosclerosis. The most thoroughly investigated polymorphisms in the literature are: C-1562T, Q279R, 836GA, R668Q, and P574R (8).

In this study, we investigated the MMP9, Q279R and P574R variations in Turkish aortic dissection patients. In addition, we analysed our results with the published epigenome, expression, and miRNA array data.

\section{MATERIALS AND METHODS}

Our study was designed as a retrospective case-control study, and a case group was built comprising 44 patients who underwent aortic dissection surgery between 2007 and 2011. The patient's diagnosis was confirmed with echocardiography and computed tomography imaging techniques that demonstrated an intimal flap with a true and a false lumen. As hypercholesterolemia, diabetes mellitus, hypertension, and hypertriglyceridemia are risk factors for aortic dissection, the patients' blood pressure, fasting glucose, triglyceride, and low-density lipoprotein levels were recorded. latrogenic, syndromic, and traumatic aortic dissection patients were excluded from the study. The control group consisted of 40 individuals with normal findings on their physical and echocardiographic examinations. This study has the ethics committee approval from Istanbul University (Istanbul Medical Faculty Clinical Research Ethics Committee; 2018/1252), and an informed consent was obtained from all selected individuals.

Genomic DNA was extracted from the peripheral blood of both the patient and control group subjects. The polymerase chain reaction (PCR) was used to amplify the targeted genomic sequences. The primers designed for the targeted regions are shown in Table 1. Amplification was conducted using a total volume of $25 \mu \mathrm{l}$ comprising: $100 \mathrm{ng}$ genomic DNA; a reaction buffer includes $25 \mathrm{mM}$ magnesium chloride and 10X potassium chloride; $1 \mathrm{U}$ Taq polymerase; $2.5 \mathrm{mM}$ deoxynucleotide; and $10 \mathrm{pmol}$ of each primer. The PCR thermal cycling steps were performed at $95^{\circ} \mathrm{C}$ for 2 minutes (initiation), $94^{\circ} \mathrm{C}$ for 30 seconds (denaturation), $55^{\circ} \mathrm{C}$ for 45 seconds (annealing), $72^{\circ} \mathrm{C}$ for 30 seconds (extension), and $72^{\circ} \mathrm{C}$ for 5 minutes (final extension). The PCR products were analyzed on a $2 \%$ agarose gel, and electrophoresis was performed at $80 \mathrm{~V}$ for 30 minutes. The prevalence of two single nucleotide polymorphisms of the MMP9 gene, Q279R, and P574R, was evaluated in the patient and control groups. The Q279R polymorphism has three genotypes: the common genotype is $\mathrm{AA}$, and the less common genotypes are AG and GG. The other studied single nucleotide polymorphism, P574R, has only two genotypes: the widespread genotype is CC, and the less common genotype is CG. The reaction products were digested with the Mspl and $\mathrm{BsrBI}$ restriction enzymes. For the digestion step, $20 \mu \mathrm{l}$ of PCR prod-

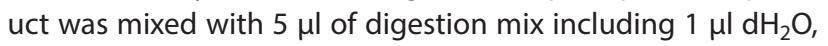
$1.5 \mu$ restriction enzyme, and $2.5 \mu$ l tango buffer. The samples were incubated at $37^{\circ} \mathrm{C}$ for 3 hours, and then electrophoresis was done for identification of the genotype.

Table 1. Details of enzyme digestion analysis

\begin{tabular}{llll}
\hline Polymorphisms & Primer & PCR Product (bp) & Restriction Enzyme \\
\hline Q279R (rs17576) & $\begin{array}{l}\text { 5'-GGCCCAATTTTCTCATCTGAG-3' } \\
\text { 3'-GAGCTTGTCCCGGTCGTA-5' }\end{array}$ & 292 & Mspl \\
\hline P574R (rs2250889) & $\begin{array}{l}\text { 5'-CTTATCGCCGACAAGTGG-3' } \\
\text { 3'-GCACAAGACGTTTCGTGG-5' }\end{array}$ & 190 & BsrBI \\
\hline
\end{tabular}


The Statistical Package for the Social Sciences software for Windows (SPSS version 25, IBM Corporation, Armonk, New York, USA) was used to perform all the statistical analyses. The Hardy-Weinberg equilibrium-based genotypes distribution prediction was used to analyze the study and control groups. The genotype distribution frequencies of the patient and control groups were compared using Fisher's exact test. The clinical features of patients and their genotype characteristics were analyzed by one-way analysis of variance, Tukey's honest significant difference tests, and the independent sample t-test. The $p$ values $<0.05$ were considered significant.

To perform the meta-analysis array data, datasets of aortic dissection patients had gotten NCBI GEO database. GSE84274, GSE52093, GSE98770 were used to analyze gene expression levels, GSE92427 was selected to explore miRNA levels on aortic dissection levels (12-15). Although datasets had more than one aortic tissue disease, we chose only the aortic dissection patients' data and control groups. First, calculations were performed through the medium of a readyto-use GEO2R program. Then,we checked the results with the Bioconductor package of R. Top 100 genes, according to their adjusted $p$-value, were selected to analyze. Obtained gene functions and relation with MMP9 were analyzed with STRING-db, UNIPROT, NCBI, PANTHER, and other commonly used databases (16-19).

\section{RESULTS}

The genotype distribution characteristics of the patient and control groups are shown in Table 2. Q279R and P574R were investigated in 84 and 77 individuals, respectively. Both the patient and control groups had similar percentages of males and females. There was a small genotype difference between the females and the males in the group of aortic dissection patients. More than half of the total number of individuals had widespread genotypes for two polymorphisms: the AA genotype was present in $56.8 \%$ of the patient group and $60 \%$ of the control group; the CC genotype was present in $87.8 \%$ of the patient group and 78\% of the control group (AA for Q279R, CC for $\mathrm{P} 574 \mathrm{R})$ ( $p=0.943$ for Q279R). Ancestral allele frequencies were different in the AD patients and dbSNP data for the two SNPs, however, they were not found statistically significant $(p=0.721$ for allele $\mathrm{A}$, and $p=0.384$ for allele $C$ ). Statistical analysis revealed an association between the P574R and aortic dissection (odds ratio $=0.486, p=0.361$ ). Also, there was a different distribution of P574R between the male and female aortic dissection patients. Female individuals had a higher risk than males (odds ratio $=0.750, p=0.361)$. However, in datasets, the male percentage is higher than females. (19 males vs 4 female patients)

The medications taken by the aortic dissection patients $(n=44)$ with respect to the genotypes of Q279R and P574R are given in Table 3. Six different pharmaceuticals were selected, and their

Table 2. Genotypes of male and female subjects in the control and aortic dissection patient groups

\begin{tabular}{|c|c|c|c|c|c|c|c|c|c|c|c|c|c|}
\hline & & \multicolumn{7}{|c|}{ Q279R } & \multicolumn{5}{|c|}{ P574R } \\
\hline & & \multicolumn{2}{|c|}{ AA } & \multicolumn{2}{|c|}{ AG } & \multicolumn{2}{|c|}{ GG } & \multirow[b]{2}{*}{ Total } & \multicolumn{2}{|c|}{ CC } & \multicolumn{2}{|c|}{ CG } & \multirow[b]{2}{*}{ Total } \\
\hline & & $\mathbf{n}$ & $\%$ & $n$ & $\%$ & $\mathbf{n}$ & $\%$ & & $\mathbf{n}$ & $\%$ & $\mathbf{n}$ & $\%$ & \\
\hline \multirow{2}{*}{ Control } & Female & 16 & 40 & 9 & 22.5 & 1 & 2.5 & 26 & 21 & 58.3 & 4 & 11.1 & 25 \\
\hline & Male & 8 & 20 & 4 & 10 & 2 & 5 & 14 & 7 & 19.4 & 4 & 11.1 & 11 \\
\hline \multirow{2}{*}{ Patients } & Female & 19 & 43.2 & 12 & 27.3 & 3 & 6.8 & 34 & 27 & 65.8 & 4 & 9.7 & 31 \\
\hline & Male & 6 & 13.6 & 3 & 6.8 & 1 & 2.3 & 10 & 9 & 21.9 & 1 & 2.4 & 10 \\
\hline$p$-value & & \multicolumn{7}{|c|}{0.943} & \multicolumn{5}{|c|}{0.361} \\
\hline
\end{tabular}

Table 3. Drugs currently used by aortic dissection patients with respect to the genotypes of Q279R and P574R

\begin{tabular}{|c|c|c|c|c|c|c|c|c|c|}
\hline & \multicolumn{5}{|c|}{ Q279R } & \multicolumn{4}{|c|}{ P574R } \\
\hline & $\mathbf{A A}$ & AG & GG & & & CC & CG & & \\
\hline & $\mathbf{n}$ & $\mathbf{n}$ & $\mathbf{n}$ & Total & $p$ value & $\mathbf{n}$ & $\mathbf{n}$ & Total & p value \\
\hline$\beta$-blocker & 13 & 7 & 4 & 24 & 0.487 & 20 & 3 & 23 & 0.732 \\
\hline ACE inhibitor & 8 & 2 & 1 & 13 & 0.182 & 12 & - & 12 & 0.123 \\
\hline Calcium channel blocker & 2 & - & 1 & 3 & 0.208 & 3 & - & 3 & 0.651 \\
\hline Acetylsalicylic acid & 5 & 3 & - & 8 & 0.718 & 8 & - & 8 & 0.281 \\
\hline Angiotensin receptor blocker & 3 & 3 & - & 6 & 0.426 & 6 & - & 6 & 0.402 \\
\hline Coumadin & 5 & 2 & - & 7 & 0.621 & 5 & 1 & 6 & 0.598 \\
\hline
\end{tabular}


relationships with the polymorphisms were analyzed. It was clear that the angiotensin-converting enzyme (ACE) inhibitor, calcium channel blocker, and acetylsalicylic acid usage was in harmony with MMP9 polymorphisms. (odds ratio $=0.682$ for coumadin, and odds ratio $=0.952$ for $\beta$-blocker).

According to their blood features, the genotype distributions of the aortic dissection patients are shown in Tables 4, 5, and 6.
The patients were grouped according to their genotypes. The mean and standard deviation values of the blood features and the widespread genotype for each group based on $p$-values and chi-squared analysis are given in Table 4. Blood glucose and potassium levels of the AG genotype as well as the alanine aminotransferase and platelet levels of the GG genotype were relative levels of significance.

Table 4. Laboratory findings according to Q279R genotypes in the patients group

\begin{tabular}{lllll}
\hline & AA & AG & GG & p-value \\
\hline Blood glucose & $153.04 \pm 60.98$ & $131.53 \pm 26.38$ & $149.25 \pm 79.12$ & 0.69 \\
\hline BUN & $24.62 \pm 12.58$ & $24.06 \pm 9.09$ & $28.25 \pm 10.75$ & 0.718 \\
\hline CR & $1.51 \pm 1.66$ & $1.35 \pm 0.57$ & $1.45 \pm 0.46$ & 0.967 \\
\hline AST & $74.82 \pm 105.93$ & $90.8 \pm 124.32$ & $83.25 \pm 76.18$ & 0.954 \\
\hline ALT & $48.21 \pm 68.52$ & $115.46 \pm 270.6$ & $225.25 \pm 295.2$ & 0.148 \\
\hline Sodium & $140.78 \pm 3.9$ & $140.66 \pm 3.71$ & $143 \pm 5.35$ & 0.461 \\
\hline Potassium & $4.17 \pm 0.55$ & $4.49 \pm 0.54$ & $4.31 \pm 0.75$ & 0.486 \\
\hline WBC & $12.31 \pm 4.8$ & $12.29 \pm 3.96$ & $11.9 \pm 3.65$ & 0.98 \\
\hline Hemoglobin & $11.51 \pm 2.33$ & $11.9 \pm 1.77$ & $10.35 \pm 0.99$ & 0.3 \\
\hline HCT & $34.03 \pm 6.50$ & $33.48 \pm 10$ & $30.42 \pm 2.36$ & $118.75 \pm 74.92$ \\
\hline PLT & $201.34 \pm 113.7$ & $207.13 \pm 80.29$ & $8.57 \pm 1.36$ & 0.614 \\
\hline MPV & $8.51 \pm 0.92$ & $8.8 \pm 1.20$ & $14.22 \pm 0.83$ & 0.183 \\
\hline RDW & $14.66 \pm 2.53$ & $15.35 \pm 2.57$ & 0.853 \\
\hline
\end{tabular}

(BUN: blood urea nitrogen, CR: creatinine, AST: aspartate aminotransferase, ALT: Alanine aminotransferase, WBC: white blood cells, HCT: hematocrit, PLT: platelet, MPV: mean platelet volume, RDW: red cell distribution width. Data are given as mean \pm standard deviation.)

Table 5. Statistical comparison ( $p$-value) of laboratory findings according to Q279R genotypes in the patients group

\begin{tabular}{llll}
\hline & AA vs. AG & AA vs. GG & AG-GG vs. AA \\
\hline Blood glucose & 0.45 & 0.99 & 0.284 \\
\hline BUN & 0.987 & 0.815 & 0.921 \\
\hline CR & 0.93 & 0.996 & 0.734 \\
\hline AST & 0.902 & 0.989 & 0.674 \\
\hline ALT & 0.536 & 0.207 & 0.131 \\
\hline Sodium & 0.996 & 0.562 & 0.762 \\
\hline Potassium & 0.215 & 0.89 & 0.112 \\
\hline WBC & 1 & 0.984 & 0.938 \\
\hline Hemoglobin & 0.84 & 0.571 & 0.919 \\
\hline HCT & 0.976 & 0.67 & 0.622 \\
\hline PLT & 0.983 & 0.292 & 0.687 \\
\hline MPV & 0.708 & 0.995 & 0.478 \\
\hline RDW & 0.678 & 0.942 & 0.556 \\
\hline
\end{tabular}

(BUN: blood urea nitrogen, CR: creatinine, AST: aspartate aminotransferase, ALT: Alanine aminotransferase, WBC: white blood cells, HCT: hematocrit, PLT: platelet, MPV: mean platelet volume, RDW: red cell distribution width.)
Alleles were compared with the blood features of the aortic dissection patients. The results of this comparison indicate that MMP9 was associated with disease progenitors. There was a distinguishable difference between alleles $A$ and $G$. The allele $G$ carriers had a risk of developing aortic dissection compared to the allele A carriers.

According to the De Bakey classification, there are three different types of aortic dissection. Type 2 involves the ascending aorta, type 3 involves the descending aorta, and type 1 aortic dissection includes both. A large majority of our patients had type 1 aortic dissections. The genotype distribution of the studied single nucleotide polymorphisms across aortic dissection types is given in Table 7. Though there was no statistical significance between the two polymorphisms and aortic dissection type, P574R has a higher impact probability on aortic dissection than Q279R. After these statistical analyses, MMP9 expression and methylation levels had not been changed on study groups of selected datasets in comparison with control groups as we expected-all these expression data were obtained from dissected aorta tissue that has the low secretion of gelatinase proteins.

Nevertheless, circulating miRNA levels had been determined by plasma, not from aortic tissue, and MMP9 targeted miRNAs 
Table 6. Laboratory findings according to P574R genotypes in the patients group

\begin{tabular}{llll}
\hline & CC & CG & p-value \\
\hline Blood glucose & $145.38 \pm 57.62$ & $137.4 \pm 23.96$ & 0.764 \\
\hline BUN & $24.62 \pm 11.2$ & $19.2 \pm 4.43$ & 0.296 \\
\hline CR & $1.47 \pm 1.39$ & $0.96 \pm 0.18$ & 0.416 \\
\hline AST & $81.58 \pm 111.7$ & $35.8 \pm 24.13$ & 0.372 \\
\hline ALT & $100.23 \pm 211.9$ & $31.6 \pm 20.71$ & 0.479 \\
\hline Sodium & $140.64 \pm 3.96$ & $140.8 \pm 3.56$ & 0.936 \\
\hline Potassium & $4.30 \pm 0.56$ & $4.25 \pm 0.30$ & 0.853 \\
\hline WBC & $12.57 \pm 4.55$ & $9.7 \pm 2.99$ & 0.181 \\
\hline Hemoglobin & $11.47 \pm 2.19$ & $12.52 \pm 1.37$ & 0.310 \\
\hline HCT & $33.9 \pm 6.25$ & $31.3 \pm 16.25$ & 0.740 \\
\hline Platelet & $201.7 \pm 106.26$ & $206.2 \pm 68.74$ & 0.928 \\
\hline MPV & $8.68 \pm 1.13$ & $8.14 \pm 0.43$ & 0.301 \\
\hline RDW & $14.72 \pm 2.39$ & $16.06 \pm 2.93$ & 0.264 \\
\hline
\end{tabular}

(BUN: blood urea nitrogen, CR: creatinine, AST: aspartate aminotransferase, ALT: Alanine aminotransferase, WBC: white blood cells, HCT: hematocrit, PLT: platelet, MPV: mean platelet volume, RDW: red cell distribution width. Data are given as mean \pm standard deviation.)

Table 7. Aortic dissection types and genotype distributions

\begin{tabular}{lccccccccc}
\hline & \multicolumn{3}{c}{ Q279R } & \multicolumn{3}{c}{ P574R } \\
\hline Type 1 & AA & AG & GG & Total & p value & CC & CG & Total & p value \\
\hline Type 2 & 1 & 13 & 4 & 39 & & 32 & 4 & 36 \\
\hline Type 3 & 2 & - & - & 1 & $\mathbf{0 . 8 6 0}$ & 1 & - & 1 & $\mathbf{0 . 4 9 7}$ \\
\hline
\end{tabular}

were found downregulated. All miRNAs were checked from TargetScanHuman (version 7.2) and miRWalk (version 2.0) $(20,21)$. 100 genes from each dataset were analyzed to find the biological pathways they relate to. MMP9 expression did not critically change in studies, but regulators of MMP9, TIMP1, and TIMP2 had been shown expression differences. However, upregulated genes were found to meet in a typical biological process, mitotic cell cycle regulation, and muscle cell construction. Downregulated genes play roles in cellular adhesion and developmental processes like angiogenesis. Also, these genes had a different affinity to chemicals and cofactors. Analysis results are given in Figure 1.

\section{DISCUSSIONS}

MMPs are known with their roles in collagen-based diseases, such as vascular rearrangement and devastation. They are divided into ligand subgroups, one of which is MMP9. A collagenase involved in extracellular matrix degradation, MMP9 directly affects collagen-based structures and has been implicated in several vascular diseases. Research on the relationship between MMPs and aortic dissection has primarily focused on the concentrations of matrix metalloproteinase proteins and inhibitors (TIMPs) in plasma and tissue.
We investigated two amino acid changes, Q279R and P574R, located on different exons of the MMP9 gene. The PolyPhen-2 prediction tool classifies Q279R and P574R as benign alleles (22). Conformational changes in protein structure which result from Q279R and P574R variations are shown in Figure 2 (23-26). Moreover, MMP9 and TIMP1/2 interactions come into existence by hemopexin-like domains of MMP9 and the C terminal of TIMP. P574R affects a hairpin structure in its place as a result of this docking of two proteins (27).

Insights into this structural information, we decided to focus on the proteins that bind directly to MMP9. In datasets GSE52093 and GSE84274, we ascertained proteins related to T cell regulation, hemopoiesis, angiogenesis, chemokine regulation, extracellular matrix binging, and vascular morphogenesis mission. Interestingly in the dataset GSE52093, some of the vital protein kinases which play roles in DNA damage, cell cycle, and apoptotic process are upregulated in dissected aorta tissue.

There was no significant association between genotypes and the patients' medications, which shows a tendency toward aortic dissection. Previous studies have shown that MMP9 is strongly linked to hypertension due to its vascular remodel- 


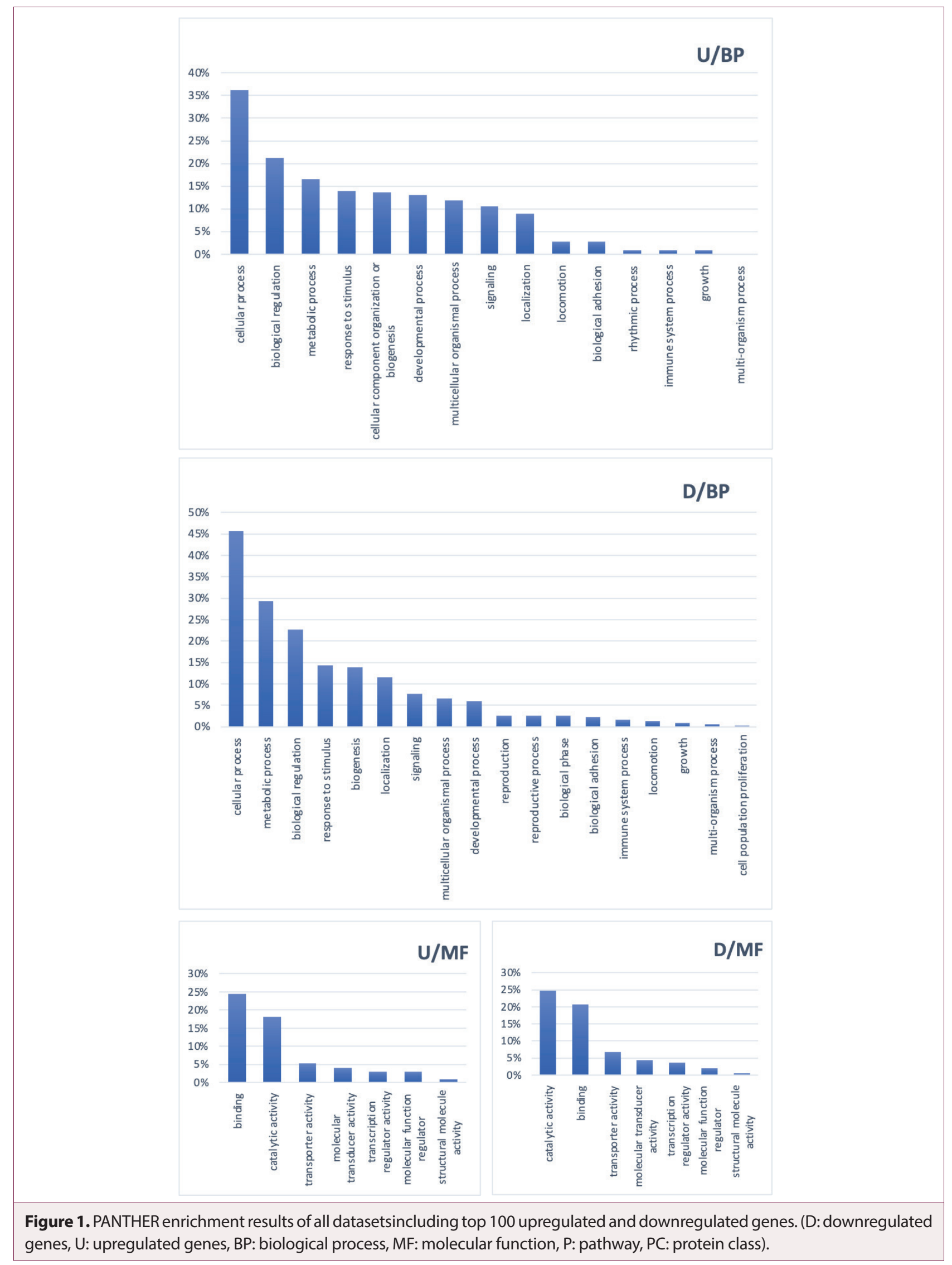




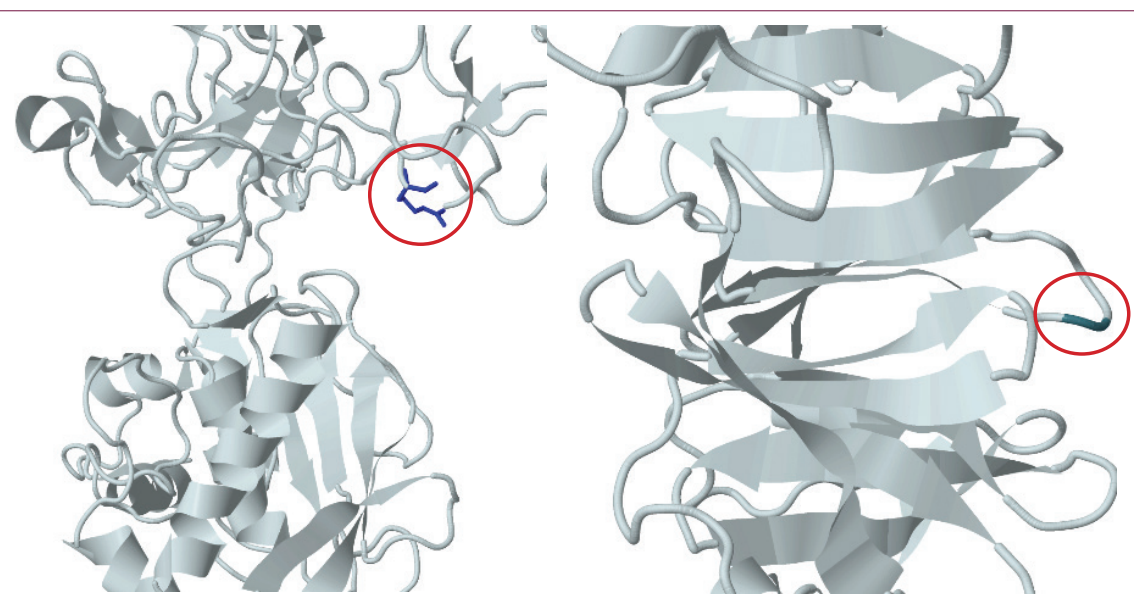

Figure 2. Secondary structures of mutant MMP9 (1- 1L6J for Q279R, 2- 1ITV for P574R).

ing properties (28). In our study, one out of every three aortic dissection patients used drugs for hypertension, a significant risk factor for aortic dissection (29). Calcium channel blockers, ACE inhibitors acetylsalicylic acid usage differed significantly among the patients carrying the homozygous ancestral alleles. The patients carrying the $\mathrm{G}$ alleles showed obvious differences in alanine aminotransferase, potassium, platelet levels for those with Q279R, potassium, and white blood cell levels P574R. Our blood testing and genotyping analyses also demonstrated platelet differences. A correlation was found between the MMP9 genotypes and acetylsalicylic acid, which blocks the blood's coagulation mechanism (30). Blood platelets and red blood cells play an essential role in coagulation. In the dataset GSE52093, JAK2 plays a role in blood coagulation expression level measured as downregulated. However, the function of MMP9 in the coagulation mechanism is still unknown. Future studies can be designed to explore the effects of MMPs on the ion channels of the cell membrane.

MMP9 affects cell membrane structure and cell proliferation. The expression of the mitotic cell cycle regulator genes had different fold changes in aorta tissue. We may speculate that single nucleotide changes on MMP9 might disrupt the cell membrane's calcium and potassium channels via binding regulatory proteins as SULF2. Calcium channels have different functions in different cell types; in cardiac tissue, calcium channels are involved in excitation-contraction coupling and pace-making properties (31). Potassium channels are directly associated with the calcium ions that activate the potassium channel. Both membrane channels are related to vascular conformation (32).

Recent studies have shown that MMPs break down nonmatrix proteins related to immune processes (33-35). The cells of the immune system not only protect the body against diseases and foreign invaders, but they also repair tissue injuries by proliferation and cell migration. These processes are triggered by chemotactic signals that are easily modified by MMPs. For instance,
MMP9 modulates T-cell function by cleaving the CD25 receptor of interleukin-2. In vivo experiments have shown that MMP9 and a second MMP type, MMP-2, assist in T cell migration. In vitro experiments have indicated that high expression levels of MMP9 and MMP-2 lead to the increased migratory capacity of type $1 \mathrm{~T}$ helper cells. MMP9 activity in both endothelial and T cells directly regulate the behavior of leukocytes and cytokine and chemokine formation. These environmental changes recruit white blood cells, an outcome supported by our study results showing that aortic dissection patients have high blood levels of leukocytes (34). In addition to these findings, aortic dissection types vary among patients. Also, MMP9 targeted proteins like MBP, RUNX2, ANGPT2, and SNAI2, which have roles in blood cell migration and immune response regulation, had a different dissected aorta tissue expression.

In conclusion, MMP9 is a collagenase that directly and/or indirectly influences vascular remodeling mechanisms. Patients carrying the $G$ allele show an increased risk of aortic dissection than the ancestral allele carriers (A for Q279R and C for P574R) in accordance with RFLP results. Our study revealed the probable relationship between the cell membrane and MMP9 proteins' ion channels with the Q279R and P574R polymorphisms. Our findings confirm that MMP9 plays a role in aortic dissection so far as pharmaceuticals listed above explain how deformation occurs on the aorta. Aortic vessel deformations resulting from true or false lumens like aortic dissection lead to many cardiovascular diseases. Besides morphological deformation, chemicals also destroy vein structure. We can say that Q279R and P574R polymorphisms of the MMP9 gene affect the extracellular matrix and cause vessel deformation in a roundabout way. Membrane organization defects might not result from MMP9 polymorphisms, but these structural changes disrupt the molecular function of matrix metalloproteinase and form a basis of aortic dissection. These polymorphisms have been studied in the aortic dissection patient group for the first time in Turkey, and it will be a pioneering work for future studies. 
Ethics Committee Approval: This study has the ethics committee approval from Istanbul University (Istanbul Medical Faculty Clinical Research Ethics Committee; 2018/1252), and an informed consent was obtained from all selected individuals.

Peer-review: Externally peer-reviewed.

Author Contributions: Concept - B.S.Y., M.S., N.A.; Data Collection B.S.Y., M.S., A.E., M.U., N.A.; Data Analysis and/or Interpretation - B.S.Y., E.E., F.C., Ö.M.G.T., N.A.; Literature Search - B.S.Y., M.S., A.E., M.U., E.E., F.C., Ö.M.G.T., N.A.; Writing - B.S.Y., M.S., N.A.

Conflict of Interest: The authors have no conflict of interest to declare.

Financial Disclosure: This work was funded by Istanbul University Scientific Research Project Unit. Project number: BAP-2019K12-149071.

Etik Komite Onayı: Bu çalışma, İstanbul Üniversitesi'nden (İstanbul Tıp Fakültesi Klinik Araştırmalar Etik Kurulu; 2018/1252) etik kurul onayına sahiptir ve seçilen tüm bireylerden bilgilendirilmiş onam alınmıştır.

\section{Hakem Değerlendirmesi: Dış bağımsız.}

Yazar Katkıları: Çalışma Konsepti - B.S.Y., M.S., N.A.; Veri Toplama - B.S.Y., M.S., A.E., M.U., N.A.; Veri Analizi/Yorumlama - B.S.Y., E.E., F.C., Ö.M.G.T., N.A.; Literatür taraması - B.S.Y., M.S., A.E., M.U., E.E., F.C., Ö.M.G.T., N.A.; Yazma - B.S.Y., M.S., N.A.

Çıkar Çatışması: Yazarlar çıkar çatışması bildirmemişlerdir.

Finansal Destek: Bu çalışma İstanbul Üniversitesi Bilimsel Araştırma Proje Birimi tarafından finanse edilmiştir. Proje numarası: BAP2019K12-149071.

\section{REFERENCES}

1. Mukherjee D, Eagle KA. Aortic dissection--an update. Curr Probl Cardiol 2005; 30: 287-325. [CrossRef]

2. Criado FJ. Aortic dissection: a 250-year perspective. Tex Heart Inst J 2011; 38: 694-700.

3. Gawinecka J, Schönrath F, von Eckardstein A. Acute aortic dissection: pathogenesis, risk factors and diagnosis. Swiss Med Wkly 2017; 147: w14489. [CrossRef]

4. Ekmekçi A, Uluganyan M, Güngör B, Abacı N, Ozcan KS, Ertaş G, et al. Association between endothelial nitric oxide synthase intron 4a/b polymorphism and aortic dissection. Turk Kardiyol Dern Ars 2014; 42: 55-60. [CrossRef]

5. Salhab K, Gioia W, Rabenstein AP, Gubernikoff G, Schubach S. Medical Management of Three Patients with an Acute Type A Aortic Dissection: Case Series and a Review of the Literature. Aorta 2018; 6: 98-101. [CrossRef]

6. Sherifova S, Holzapfel GA. Biomechanics of aortic wall failure with a focus on dissection and aneurysm: A review. Acta Biomater 2019; 99: 1-17. [CrossRef]

7. Zitka O, Kukacka J, Krizkova S, Huska D, Adam V, Masarik M, et al. Matrix metalloproteinases. Curr Med Chem 2010; 17: 3751-68. [CrossRef]

8. Yabluchanskiy A, Ma Y, lyer RP, Hall ME, Lindsey ML. Matrix metalloproteinase-9: Many shades of function in cardiovascular disease. Physiology 2013; 28: 391-403. [CrossRef]
9. O'Farrell TJ, Pourmotabbed T. The fibronectin-like domain is required for the type $\mathrm{V}$ and $\mathrm{XI}$ collagenolytic activity of gelatinase $\mathrm{B}$. Arch Biochem Biophys 1998; 354: 24-30. [CrossRef]

10. Papazafiropoulou A, Tentolouris N. Matrix metalloproteinases and cardiovascular diseases. Hippokratia 2009; 13: 76-82.

11. Brown DL, Hibbs MS, Kearney M, Loushin C, Isner JM. Identification of $92-\mathrm{kD}$ gelatinase in human coronary atherosclerotic lesions. Association of active enzyme synthesis with unstable angina. Circulation 1995; 9: 2125-31. [CrossRef]

12. Pan $\mathrm{S}$, Lai $\mathrm{H}$, Shen $\mathrm{Y}$, Breeze $\mathrm{C}$, Beck $\mathrm{S}$, Hong $\mathrm{T}$, et al. DNA methylome analysis reveals distinct epigenetic patterns of ascending aortic dissection and bicuspid aortic valve. Cardiovasc Res 2017; 113: 692-704. [CrossRef]

13. Pan $S$, Wu D, Teschendorff AE, Hong $T$, Wang $L$, Qian $M$, et al. JAK2-centered interactome hotspot identified by an integrative network algorithm in acute Stanford type A aortic dissection. PLoS One 2014; 9: e89406. [CrossRef]

14. Kimura N, Futamura K, Arakawa M, Okada N, Emrich F, Okamura H, et al. Gene expression profiling of acute type A aortic dissection combined with in vitro assessment. Eur J Cardiothorac Surg 2017; 52: 810-7. [CrossRef]

15. Dong J, Bao J, Feng R, Zhao Z, Lu Q, Wang G, et al. Circulating microRNAs: a novel potential biomarker for diagnosing acute aortic dissection. Sci Rep 2017; 7: 12784. [CrossRef]

16. Barrett T, Wilhite SE, Ledoux P, Evangelista C, Kim IF, Tomashevsky $M$, et al. NCBI GEO: archive for functional genomics data sets--update. Nucleic Acids Res 2013; 41: D991-5. [CrossRef]

17. Szklarczyk D, Gable AL, Lyon D, Junge A, Wyder S, Huerta-Cepas J, et al. STRING v11: protein-protein association networks with increased coverage, supporting functional discovery in genome-wide experimental datasets. Nucleic Acids Res 2019; 47: D607-D613. [CrossRef]

18. UniProt Consortium. UniProt: a worldwide hub of protein knowledge. Nucleic Acids Res 2019; 47: D506-D515. [CrossRef]

19. Mi H, Muruganujan A, Ebert D, Huang X, Thomas PD. PANTHER version 14: more genomes, a new PANTHER GO-slim and improvements in enrichment analysis tools. Nucleic Acids Res 2019; 47: D419-D426. [CrossRef]

20. Lewis BP, Burge CB, Bartel DP. Conserved seed pairing, often flanked by adenosines, indicates that thousands of human genes are microRNA targets. Cell 2005; 120: 15-20. [CrossRef]

21. Sticht C, De La Torre C, Parveen A, Gretz N. miRWalk: An online resource for prediction of microRNA binding sites. PLoS One 2018; 13: e0206239. [CrossRef]

22. Adzhubei IA, Schmidt S, Peshkin L, Ramensky VE, Gerasimova A, Bork $\mathrm{P}$, et al. A method and server for predicting damaging missense mutations. Nat Methods 2010; 7: 248-9. [CrossRef]

23. Burley SK, Berman HM, Bhikadiya C, Bi C, Chen L, Di Costanzo L, et al. RCSB Protein Data Bank: biological macromolecular structures enabling research and education in fundamental biology, biomedicine, biotechnology and energy. Nucleic Acids Res 2019; 47: D464-D474. [CrossRef]

24. Elkins PA, Ho YS, Smith WW, Janson CA, D'Alessio KJ, McQueney MS, et al. Structure of the C-terminally truncated human ProMMP9, a gelatin-binding matrix metalloproteinase. Acta Crystallogr D Biol Crystallogr 2002; 58: 1182-92. [CrossRef]

25. Cha H, Kopetzki E, Huber R, Lanzendörfer M, Brandstetter H. Structural basis of the adaptive molecular recognition by MMP9. J Mol Biol 2002; 320: 1065-79. [CrossRef]

26. SIttisoponpisan S, Islam SA, Khanna T, Alhuzimi E, David A, Sternberg MJE. Can Predicted Protein 3D Structures Provide Reliable Insights into whether Missense Variants Are Disease Associated? J Mol Biol 2019; 431: 2197-212. [CrossRef] 
27. Kuhlman B, Bradley P. Advances in protein structure prediction and design. Nat Rev Mol Cell Biol 2019; 20: 681-97. [CrossRef]

28. Galis ZS, Khatri JJ. Matrix metalloproteinases in vascular remodeling and atherogenesis: the good, the bad, and the ugly. Circ Res 2002; 90: 251-62. [CrossRef]

29. Wen D, Zhou XL, Li JJ, Hui RT. Biomarkers in aortic dissection. Clin Chim Acta 2011; 412: 688-95. [CrossRef]

30. Roth GJ, Majerus PW. The mechanism of the effect of aspirin on human platelets. I. Acetylation of a particulate fraction protein. J Clin Invest 1975; 56: 624-32. [CrossRef]

31. Catterall WA, Perez-Reyes E, Snutch TP, Striessnig J. International Union of Pharmacology. XLVIII. Nomenclature and structure-function relationships of voltage-gated calcium channels. Pharmacol Rev 2005; 57: 411-25. [CrossRef]
32. Sobey CG. Potassium channel function in vascular disease. Arterioscler Thromb Vasc Biol 2001; 21: 28-38. [CrossRef]

33. Gong Y, Hart E, Shchurin A, Hoover-Plow J. Inflammatory macrophage migration requires MMP-9 activation by plasminogen in mice. J Clin Invest 2008; 118: 3012-24. [CrossRef]

34. Smigiel KS, Parks WC. Matrix Metalloproteinases and Leukocyte Activation. Prog Mol Biol Transl Sci 2017; 147: 167-95. [CrossRef]

35. Snitker S, Xie K, Ryan KA, Yu D, Shuldiner AR, Mitchell BD, et al. Correlation of circulating MMP-9 with white blood cell count in humans: effect of smoking. PLoS One 2013; 8: e66277. [CrossRef] 